\title{
Non-Valve Cardiac Conduit Tissue
}

National Cancer Institute

\section{Source}

National Cancer Institute. Non-Valve Cardiac Conduit Tissue. NCI Thesaurus. Code C133339.

T issue derived from a cardiac outflow tract from which the valve structure is rendered nonfunctional, or a segment of cardiac conduit. 